\title{
Correlative Ultrastructural Distribution of Neurotensin Receptor Proteins and Binding Sites in the Rat Substantia Nigra
}

\author{
H. Boudin, ${ }^{1}$ D. Pélaprat, ${ }^{2}$ W. Rostène, ${ }^{2}$ V. M. Pickel, ${ }^{3}$ and A. Beaudet ${ }^{1}$ \\ ${ }^{1}$ Montreal Neurological Institute, McGill University, Montreal, Quebec, Canada, H3A 2B4, 2Institut National de la Santé et \\ de la Recherche Médicale U-339, Hôpital St. Antoine, 75571 Paris Cedex 12, France, and ${ }^{3}$ Department of Neurology and \\ Neuroscience, Cornell University Medical College, New York, New York 10021
}

Neurotensin (NT) produces various stimulatory effects on dopaminergic neurons of the rat substantia nigra. To gain insight into the subcellular substrate for these effects, we compared by electron microscopy the distribution of immunoreactive highaffinity NT receptor proteins (NTRH) with that of high-affinity ${ }^{125} \mathrm{I}-\mathrm{NT}$ binding sites in this region of rat brain. Quantitative analysis showed a predominant association of immunogold and radioautographic labels with somata and dendrites of presumptive dopaminergic neurons, and a more modest localization in myelinated and unmyelinated axons and astrocytic leaflets. The distributions of immunoreactive NTRH and ${ }^{125} \mathrm{I}-\mathrm{NT}$ binding sites along somatodendritic plasma membranes were highly correlated and homogeneous, suggesting that membrane-targeted NTRH proteins were functional and predominantly extrasynaptic. Abundant immunocytochemically and radioautographically labeled receptors were also detected inside perikarya and dendrites. Within perikarya, these were found in comparable proportions over membranes of smooth endoplasmic reticulum and Golgi apparatus, suggesting that newly synthesized receptor proteins already possess the molecular and conformational properties required for effective ligand binding. By contrast, dendrites showed a proportionally higher concentration of immunolabeled than radiolabeled intracellular receptors. A fraction of these immunoreactive receptors were found in endosomes, suggesting that they had undergone ligand-induced internalization and were under a molecular conformation and/or in a physical location that precluded their recognition by and/or access to exogenous ligand. Our results provide the first evidence that electron microscopic immunocytochemistry of the NT receptor identifies sites for both the binding and trafficking of NT in the substantia nigra.

Key words: electron microscopy; basal ganglia; immunogold; radioautography; internalization; G-protein-coupled receptor
Neurotensin (NT) is well known for its regulatory role on midbrain dopaminergic (DA) cells (for review, see Kasckow and Nemeroff, 1991). For instance, intracerebral administration of NT induces hypothermia (Kalivas et al., 1985) and hyperlocomotion (Kalivas et al., 1983; Cador et al., 1985) through dopaminemediated mechanisms. Furthermore, application of NT both in vivo through microiontophoretical injection of the peptide in the ventral midbrain (Shi and Bunney, 1992) and in vitro onto midbrain slices (Pinnock et al., 1985; Jiang et al., 1994) produces a direct excitatory effect on mesencephalic DA cells. This selective excitation of DA neurons results from the modulation of both $\mathrm{K}^{+}$ and nonselective cation channels (Wu et al., 1995; Chien et al., 1996) and is transduced by $\mathrm{G}_{\alpha \mathrm{q}}$ - and/or $\mathrm{G}_{\alpha 11}$-proteins as demonstrated in neurons from the substantia nigra ( $\mathrm{SN}$ ) in primary culture (Wang and Wu, 1996). Microinjections of NT into the SN also stimulate a local release of DA concomitant with an enhancement of DA turnover in the globus pallidus and striatum, major projection areas of nigral DA efferents (Myers and Lee, 1983; Napier et al., 1985).

\footnotetext{
Received Jan. 16, 1998; revised July 28, 1998; accepted July 30, 1998.

This work was supported by a grant from the Medical Research Council of Canada, a NATO Travel Exchange Program, and an Institut National de la Santé et de la Recherche Médicale-Fonds de la Recherche en Santé du Québec fellowship to H.B. We thank Mariette Houle and Christian Charbonneau for expert technical assistance.

Correspondence should be addressed to Dr. Alain Beaudet, Montreal Neurological Institute, McGill University, 3801 University Street, Montreal, Quebec, Canada, H3A 2 B4.

Copyright (C) 1998 Society for Neuroscience $\quad 0270-6474 / 98 / 188473-12 \$ 05.00 / 0$
}

Consistent with the existence of direct physiological effects of NT on midbrain DA neurons is the demonstration that highaffinity NT receptors (NTRH; $\left.K_{\mathrm{d}}=0.3 \mathrm{nM}\right)$ are associated with these cells (Palacios and Kuhar, 1981; Quirion et al., 1985; Szigethy and Beaudet, 1989; Nicot et al., 1995). A second population of NT receptors, displaying a lower affinity for NT $\left(\mathrm{NTRL} ; K_{\mathrm{d}}=\right.$ $3 \mathrm{nM}$ ) and a sensitivity toward the antihistamine levocabastine, was recently cloned in adult rat and mouse brain (Chalon et al., 1996; Mazella et al., 1996), which may also contribute to NT binding in the SN (Sarret et al., 1998).

Physiologically, NT itself was shown to regulate tonically the number of active DA neurons in the ventral midbrain through the NTRH (Santucci et al., 1997). This finding is consistent with the presence of a dense network of NT-containing axon terminals interspersed among DA neurons throughout the SN and ventral tegmental area (Jennes et al., 1982; Hökfelt et al., 1984). Only a small proportion of NT-immunoreactive terminals in either region, however, exhibit synaptic contacts with $\mathrm{TH}$-immunoreactive elements (Bayer et al., 1991; Woulfe and Beaudet, 1992). Accordingly, within the ventral tegmental area, ${ }^{125} \mathrm{I}-\mathrm{NT}$ binding sites were found by electron microscopic radioautography to be widely distributed over somatic and dendritic plasma membranes rather than confined to synaptic junctions or sites of terminal appositions (Dana et al., 1989).

Nothing is known, however, of the subcellular distribution of NTRH in the SN or whether differences in the distribution of the receptor in subsets of dopaminergic neurons might account for the differential response of SN and ventral tegmental area neu- 
rons to local application of exogenous NT (Ford and Mardsen, 1990; Rivest et al., 1991). It is also unclear whether the distribution of ${ }^{125}$ I-NT binding sites in the SN reflects that of all NTRH or merely of a subpopulation of these. To examine these issues, we took advantage of the availability of a recently developed NTRH antiserum (Boudin et al., 1995, 1996) to examine the ultrastructural localization of NTRH proteins labeled by immunogold technique in the SN. This localization was compared with the distribution of high-affinity NT binding sites labeled by highresolution radioautography. The results provide the first electron microscopic evidence for the existence of two distinct pools of NT receptors, one membrane-associated that recognizes NT and one intracellular that is only partly recognized by the exogenous ligand.

\section{MATERIALS AND METHODS}

Experiments were performed on adult male Sprague Dawley rats (200$250 \mathrm{gm}$ ) maintained on a $12 \mathrm{hr}$ light/dark cycle and fed ad libitum. All animal-related procedures were approved by the McGill University Animal Care Committee.

\section{Immunocytochemistry}

Tissue preparation. Rats $(n=5)$ were anesthetized with pentobarbital (70 $\mathrm{mg} / \mathrm{kg}$ ) and perfused transaortically with $30 \mathrm{ml}$ of heparin $(100 \mathrm{U} / \mathrm{ml}$ heparin in $0.9 \% \mathrm{NaCl}$ ), sequentially followed by a mixture of $50 \mathrm{ml}$ of $3.75 \%$ acrolein and $2 \%$ paraformaldehyde in $0.1 \mathrm{M}$ phosphate buffer

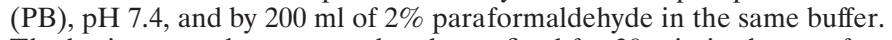
The brains were then removed and post-fixed for $30 \mathrm{~min}$ in the paraformaldehyde solution. Coronal sections ( $40 \mu \mathrm{m}$ thick) were cut on a vibratome and collected in PB. To assess the topographic distribution of NTRH immunoreactivity, a few sections were then processed for light microscopic immunohistochemistry using a standard immunoperoxidase staining technique as described previously (Boudin et al., 1996). All other sections were processed for immunogold labeling according to the protocol established by Chan et al. (1990). Briefly, tissue sections were incubated in a solution of $1 \%$ sodium borohydride in PB for 30 min to neutralize free aldehyde groups and rinsed extensively with PB. They were then cryoprotected for $30 \mathrm{~min}$ in a solution of $25 \%$ sucrose and $3 \%$ glycerol in $0.05 \mathrm{M} \mathrm{PB}$, rapidly frozen in isopentane at $-60^{\circ} \mathrm{C}$, transferred to liquid nitrogen, and thawed in $\mathrm{PB}$ at room temperature. Sections were

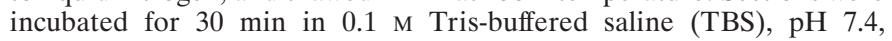
containing $3 \% \mathrm{NGS}$, followed by $16 \mathrm{hr}$ at $4^{\circ} \mathrm{C}$ in rabbit NTRH antiserum diluted 1:300 in TBS containing $0.5 \%$ NGS. This antiserum is an affinitypurified polyclonal antiserum generated against a segment of the third intracellular loop of the NTRH and has been fully characterized previously (Boudin et al., 1995, 1996). Sections were then rinsed in 0.01 M PBS (0.01 M PB, pH 7.4, containing $0.9 \% \mathrm{NaCl}$ ), incubated for $2 \mathrm{hr}$ in a 1:50 dilution of colloidal gold (1 nm)-conjugated goat anti-rabbit IgG (Amersham, Arlington Heights, IL) diluted in PBS containing $0.2 \%$ gelatin and $0.8 \%$ bovine serum albumin, and fixed for $10 \mathrm{~min}$ in $2 \%$ glutaraldehyde in PBS. After several washes in $0.2 \mathrm{M}$ citrate buffer, $\mathrm{pH}$ 7.4, immunogold was silver-enhanced by incubation for $7 \mathrm{~min}$ in the silver solution of IntenSE M kit (Amersham). The reaction was stopped by washes in citrate buffer, and sections were prepared for electron microscopy as described below. Sections were then post-fixed with $2 \%$ osmium tetroxide in $0.1 \mathrm{M} \mathrm{PB}$ for $40 \mathrm{~min}$, dehydrated in graded ethanols and propylene oxide, and flat-embedded in Epon 812 between two sheets of acetate. Ultrathin sections $(80 \mathrm{~nm})$ were collected from the SN, pars compacta. The ultrathin sections were then counterstained with lead citrate and uranyl acetate and examined with a JEOL 100CX electron microscope. Control experiments were conducted after the same protocol except that the primary antiserum was omitted during the immunohistochemical procedure.

Quantitative analysis. The subcellular distribution of silver-enhanced gold particles was analyzed quantitatively in sections from three animals. For each rat, surface sections from three different blocks were systematically scanned with the electron microscope. Each labeled element was photographed at an original magnification of $10-14,000 \times$ to reach a total number of 650 particles per animal (200-225 particles/block). Additional sections from tissue incubated in the absence of primary antibodies were also scanned in each animal to assess the density of nonspecific background labeling. In this case, all silver-gold particles present over a randomly selected surface of $200 \mu \mathrm{m}^{2} /$ grid (three grids/animal) were recorded and compared with the number of particles recorded over the same surface in sections incubated with the primary antibody. Results were pooled for each animal, averaged between animals, and expressed as a mean \pm SEM.

Gold particles from the first scan were then classified according to the type of element with which they were associated (neuronal vs glial; dendritic vs somatic or axonal) and whether they were associated with cytoplasm or plasma membrane (Peters et al., 1991). Because many labeled structures, particularly small ones such as unmyelinated axons, exhibited only one gold particle per cross-sectional profile and because overall background labeling accounted for only $1.9 \pm 0.5$ particles/100 $\mu \mathrm{m}^{2}$ (total number of particles counted: 34 ) as opposed to $28.5 \pm 2.3$ for specific labeling (total number of particles counted: 513), we elected to consider each silver-enhanced gold particle as a specific labeling site. Admittedly, a small number of nonspecifically labeled structures may thus have been erroneously included in our sampling. However, we felt that this was preferable to biasing our sampling against small and/or less intensely labeled elements. A gold particle was considered to be associated with the plasma membrane when it contacted or overlaid it. Gold particles that did not contact the plasma membrane, even if close, were classified as intracellular. The latter were ascribed either to the cytoplasm or, where possible, to underlying intracellular organelles (Golgi apparatus, endoplasmic reticulum, vesicles, mitochondria). The different profiles (dendrites, axons, axon terminals, glia) abutting immunogoldlabeled elements were also recorded, and the length of the plasma membrane that was occupied was measured using a computer-assisted image analysis system (Historag; Biocom, Les Ulis, France). If present, the length of synaptic specializations between abutting and contacted elements was also measured. Finally, surface areas of immunoreactive dendrites were measured to determine whether there was a correlation between the size of dendrites and the ratio of intracellular/membraneassociated gold particles.

\section{Radioautography}

Tissue preparation. Rats $(n=4)$ were anesthetized as above and fixed by perfusion with $500 \mathrm{ml}$ of an ice-cold fixative solution containing $1 \%$ tannic acid, $0.75 \%$ paraformaldehyde, and $0.1 \%$ glutaraldehyde in $0.12 \mathrm{M}$ $\mathrm{PB}, \mathrm{pH}$ 7.4. The brain was dissected out, and the ventral midbrain was blocked on ice and sectioned on a vibratome, at 70-75 $\mu \mathrm{m}$ thickness, in ice-cold $0.12 \mathrm{M} \mathrm{PB}$. Slices were immediately incubated for $60 \mathrm{~min}$ at $4^{\circ} \mathrm{C}$ with $0.1 \mathrm{~nm}$ monoiodo ${ }^{125} \mathrm{I}_{-} \mathrm{Tyr}^{3}-\mathrm{NT}\left[{ }^{125} \mathrm{I}-\mathrm{NT}, 2000 \mathrm{Ci} / \mathrm{mmol}\right.$; for details on iodination and purification, see Sadoul et al. (1984)] in $50 \mathrm{~mm}$ ice-cold Tris-HCl buffer, $\mathrm{pH} 7.4$, supplemented with $5 \mathrm{mM} \mathrm{MgCl}_{2}, 0.2 \%$ bovine serum albumin, $2 \times 10^{-5} \mathrm{M}$ bacitracin, and $0.25 \mathrm{M}$ sucrose. For assessment of nonspecific binding, incubations were performed in the presence of $500 \mathrm{~nm}$ nonradioactive NT. At the end of the incubation, slices were rinsed in four consecutive baths $\left(2 \mathrm{~min}\right.$ each) of fresh buffer at $4^{\circ} \mathrm{C}$. The slices were then fixed for $30 \mathrm{~min}$ at $4^{\circ} \mathrm{C}$ by immersion in a solution of $4 \%$ glutaraldehyde in $0.05 \mathrm{M} \mathrm{PB}$ and post-fixed for $1 \mathrm{hr}$ at room temperature in a $2 \%$ osmium tetroxide solution containing $7 \%$ dextrose.

To assess the specificity of the labeling and to compare the regional distribution of the label with that obtained by immunohistochemistry, some of the labeled slices were directly mounted on gelatinized glass slides and radioautographed by apposition to ${ }^{3} \mathrm{H}$-Ultrofilm (LKBWallac, Gaithersburg, MD) (Dana et al., 1989). For electron microscopic radioautography, slices were dehydrated in graded ethanols and flatembedded in Epon between two plastic coverslips. While in the last dehydration bath, the radioactivity retained in each slice was measured in a gamma counter (Compac 120, Picker) for determination of total and nonspecific binding. After overnight curing, Epon-embedded slices were trimmed down to the SN, pars compacta, re-embedded in Beem capsules, and further polymerized for 16-18 hr. Ultrathin sections $(80 \mathrm{~nm})$ were cut from the surface of each block, collected on parlodion-coated slides, double-stained with uranyl acetate and lead citrate, coated with carbon, and dipped into Ilford L-4 emulsion diluted 1:4 with distilled water. After 8-12 weeks of exposure, the radioautographs were developed in D-19 (diluted $1: 4 ; 1 \mathrm{~min}$ at $20^{\circ} \mathrm{C}$ ), fixed with $30 \%$ sodium thiosulfate, picked up on copper grids, and examined with an electron microscope after thinning the parlodion membrane in amyl acetate.

Quantitative analysis. All sites labeled in electron microscopic radioautographs from surface sections of six total and four blank slices (i.e., slices incubated in the absence and the presence of nonradioactive NT, respectively) were systematically photographed at an initial magnification of $10,000 \times$. The distribution of silver grains was analyzed using com- 


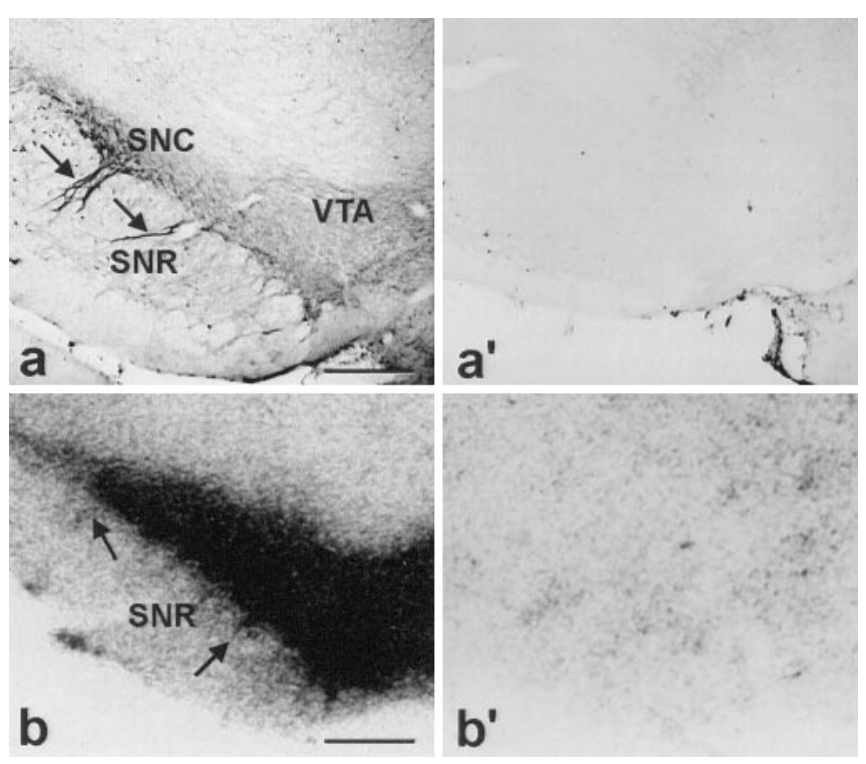

Figure 1. Light microscopic distribution of NTRH immunoreactivity ( $a$, $\left.a^{\prime}\right)$ and radioautographic distribution of bound ${ }^{125} \mathrm{I}-\mathrm{NT}\left(b, b^{\prime}\right)$ in the rat ventral mesencephalon. Sections 40 and $75 \mu \mathrm{m}$ thick, respectively, were processed using immunoperoxidase $\left(a, a^{\prime}\right)$ and "dry" radioautography $(b$, $\left.b^{\prime}\right)$. For both markers, specific signal is prominent in the substantia nigra, pars compacta $(S N C)$, and ventral tegmental area $(V T A)$, with dendrites extending in the pars reticulata (SNR; arrows). Note the lower sensitivity but higher resolution of the histochemical, as compared with autoradiographic, signal. Control sections immunoreacted with Abi3 antiserum preadsorbed with $0.1 \mu \mathrm{g} / \mathrm{ml}$ of antigenic peptide $\left(a^{\prime}\right)$ or incubated with ${ }^{125} \mathrm{I}-\mathrm{NT}$ in the presence of $500 \mathrm{nM}$ nonradioactive NT $\left(b^{\prime}\right)$ are totally devoid of labeling. Scale bars, $500 \mu \mathrm{m}$.

bined $50 \%$ probability circles and line source analyses as previously described (Hamel and Beaudet, 1987; Dana et al., 1989; Beaudet, 1993). Briefly, resolution circles (diameter $0.3 \mu \mathrm{m}$ ) drawn on a transparent overlay were superimposed over each grain (total: $n=1632$; nonspecific: $n=534$ ), and the structure (exclusive grains) or combination of structures (shared grains) included inside the circles was recorded and tabulated (see Fig. $4 b$ ). A population of uniformly distributed hypothetical grains $(n=9694)$, generated by superimposing a regular array of resolution circles over the same micrographs, was similarly analyzed. The distribution of real grains recorded in each section (blanks as well as totals) was then normalized to compensate for variations in the representation of the various tissue compartments, using the distribution of hypothetical grains as an index of their relative importance in each section. The number of silver grains recorded within each tissue compartment in blank sections was then reduced as a function of nonspecific to total binding ratios as determined in whole slices by gamma counting (see above). The resulting distribution was subtracted from that in total sections and normalized to 100 to determine the distribution of specific binding. Distributions of specific and nonspecific binding were then statistically compared with one another as well as with that of hypothetical grains by $\chi^{2}$ analysis. To assess the distribution of specific ${ }^{125} \mathrm{I}-\mathrm{NT}$ binding sites, the labeling frequency of membrane interfaces involving dendrites [i.e., dendrite/terminal, dendrite/dendrite, dendrite/axon, dendrite/glia categories (see Table 1)] was compared with that with which dendritic membranes were found in association with terminals, dendrites, axons and glia in the hypothetical grain distribution. All calculations were performed using a specifically written computer program (for further details, see mathematical appendix in Beaudet, 1993).

\section{RESULTS}

\section{Regional light microscopic distribution of NTRH}

In sections from the rat midbrain, NTRH immunolabeling was found by light microscopy to be selectively associated with neuronal perikarya and dendrites throughout the $\mathrm{SN}$ and ventral tegmental area (Fig. 1a). Immunolabeled dendrites were partic-

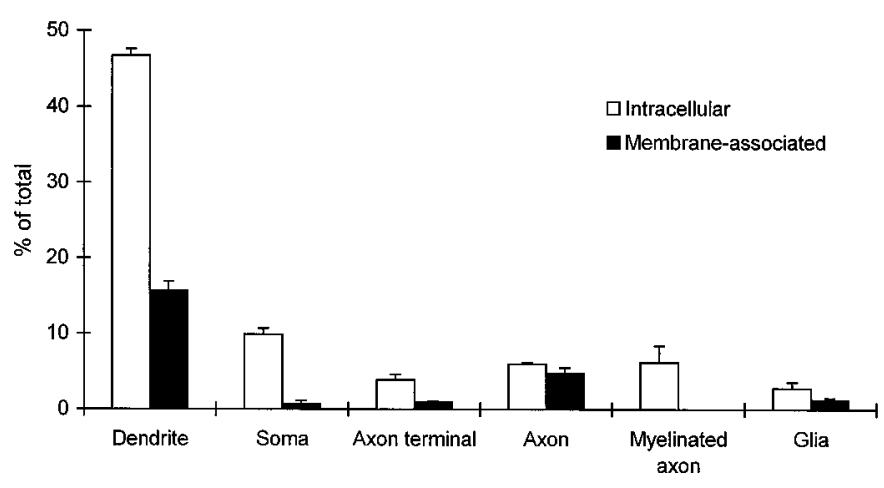

Figure 2. Quantitative analysis of the ultrastructural distribution of immunoreactive NTRH receptors detected inside or on the plasma membrane of dendrites, somas, axon terminals, unmyelinated axons (Axon), myelinated axons, and glial cells in the substantia nigra, pars compacta. Percentages (mean \pm SEM) are based on the number of gold particles observed in ultrathin sections from three animals (out of a total of 650 particles/animal).

ularly numerous in the $\mathrm{SN}$, pars compacta and also seen in bundles extending down toward the substantia nigra, pars reticulata (Fig. 1a). Control sections in which the primary antiserum had been immunoabsorbed with antigenic peptide showed minimal background staining (Fig. $1 a^{\prime}$ ).

Film radioautograms of prefixed, vibratome-cut slices from the ventral midbrain incubated with ${ }^{125} \mathrm{I}-\mathrm{NT}$ alone (total binding) exhibited an intense and selective labeling of the ventral tegmental area and SN, pars compacta (Fig. $1 b$ ). This radioautographic labeling pattern was comparable to that of NTRH immunostaining (Fig. 1, compare $a, b$ ). Slices incubated in the presence of 500 nM nonradioactive NT (nonspecific binding) showed only weak and diffuse radiolabeling (Fig. 1 $b^{\prime}$ ). Subtraction of nonspecific from total binding (as measured in whole slices by gamma counting) indicated that, in the SN, specific ${ }^{125} \mathrm{I}-\mathrm{NT}$ binding accounted for $66 \pm 3 \%$ of total.

\section{Cellular distribution of NTRH immunoreactivity and ${ }^{125} \mathrm{I}-\mathrm{NT}$ binding sites}

In conformity with light microscopic observations, most of the NTRH immunoreactivity detected by immunogold electron microscopy in the $\mathrm{SN}$, pars compacta was associated with nerve cell bodies (10.6\% of total) (Figs. 2, 3a,b) and dendrites $(62.2 \%$ of total) (Figs. 2, 4a). The remainder of silver-enhanced gold particles were observed over unmyelinated axons (10.8\%), myelinated axons (6.2\%) (Figs. 2, 3c), and axon terminals (4.8\%) (Fig. 2). A few gold particles were also associated with glial cells (4.1\%). Most NTRH-immunoreactive dendrites measured between 1 and $3 \mu \mathrm{m}$ in diameter, although labeling was also seen in a few smaller dendritic branchlets and spines $(0.5-1 \mu \mathrm{m}$ in diameter) as well as in larger dendritic trunks (3-6 $\mu \mathrm{m}$ in diameter) (Fig. 4a). Labeled dendrites contained an average of three to four gold particles per cross-sectional plane, but sometimes exhibited up to 50 gold particles in single longitudinal sections. Immunopositive unmyelinated axons were small and usually present in bundles with other unmyelinated and/or myelinated axons. NTR-immunoreactive axon terminals contained numerous small synaptic vesicles but no large dense-core vesicles. Although most of labeled axons and axon terminals contained only one or two gold particles per plane of section, a few myelinated axons showed up to six particles.

Because of the lower resolution of the radioautographic technique, the electron microscopic distribution of specifically labeled ${ }^{125}$ I-NT binding sites had to be assessed statistically, by probabil- 

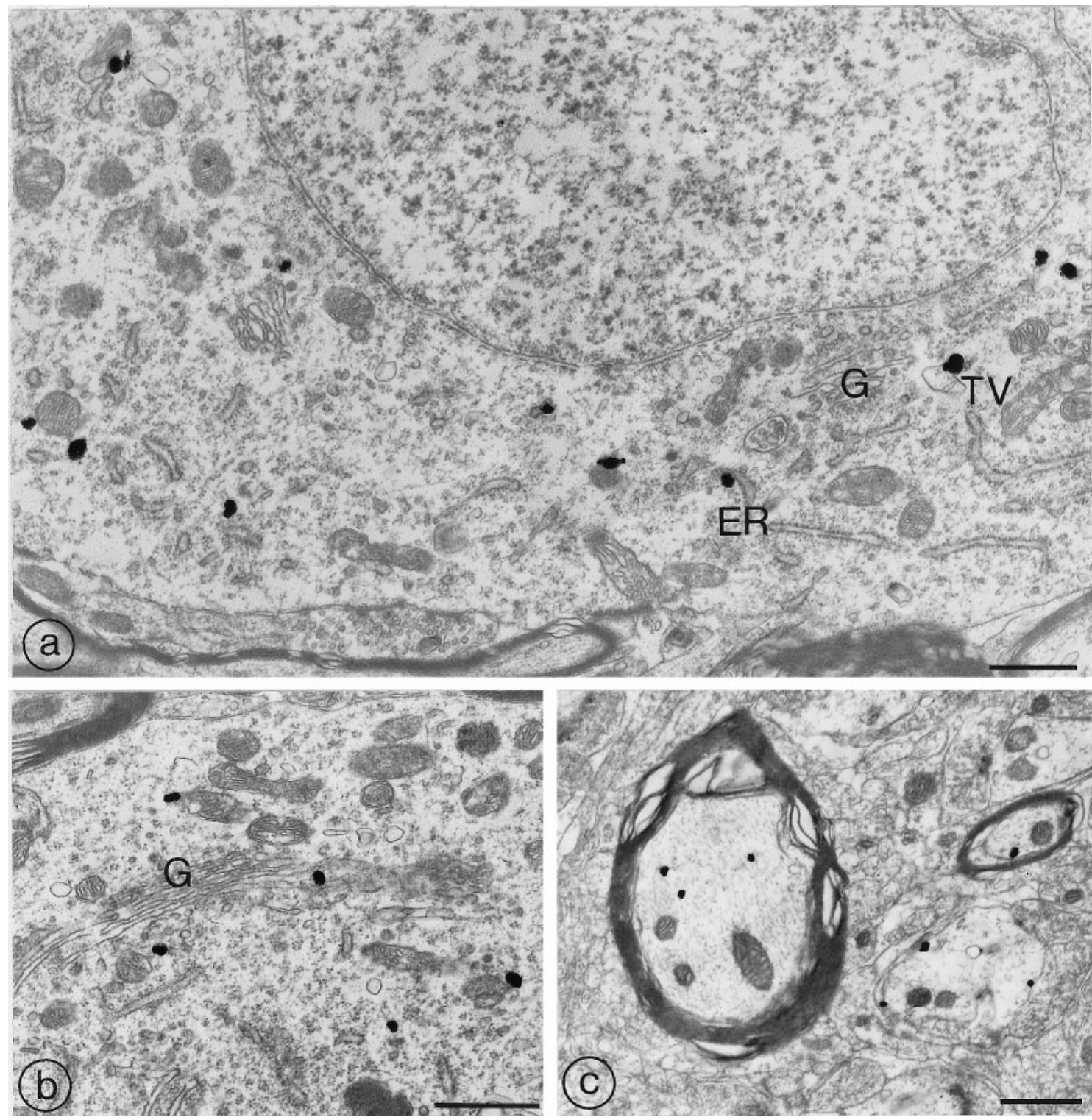

Figure 3. Electron micrographs showing immunoreactivity of immunogold-labeled NTRH receptors in neuronal cell bodies $(a, b)$, myelinated axons, and dendrite $(c) . a, b$, Within neuronal cell bodies, gold particles are seen in association with endoplasmic reticulum $(E R)$, Golgi apparatus $(G)$, and tubulovesicles $(T V)$ located in the vicinity of the Golgi apparatus. $c$, Although immunogold particles associated with myelinated axons are predominantly intracytoplasmic, those associated with the dendritic shaft are all on the plasma membrane. Scale bars, $0.6 \mu \mathrm{m}$.

ity circle analysis (Fig. 4b). This method allowed us to mathematically determine the distribution of specific ${ }^{125}$ I-NT binding sites by subtracting nonspecific from total binding as described in Materials and Methods. The distribution of specifically labeled ${ }^{125} \mathrm{I}-\mathrm{NT}$ binding sites was statistically different from that of nonspecifically labeled ones $(p<0.001)$ (Table 1$)$. Both distributions in turn were significantly different from that of hypothetical grains uniformly distributed over the same sections $(p<0.001)$ (Table $1)$. All three distributions could be divided into two broad categories of grains: (1) exclusive grains, for which the resolution circles encompassed a single neuronal or glial structure, and (2) shared grains, for which the resolution circles encompassed two or more cellular membrane interfaces (Fig. 4b). As demonstrated previously using line source analysis (Dana et al., 1989) and later confirmed by combined immunocytochemistry and radioautography (Marcel et al., 1990), exclusive grains may be ascribed mainly to intracellular radioactive sources and shared grains may be ascribed to sources associated with either one of the apposed plasma membranes present within the circle. Because ${ }^{125} \mathrm{I}-\mathrm{NT}$ binding sites had previously been shown to be associated almost exclusively with DA perikarya and dendrites in the SN (Palacios and Kuhar, 1981; Szigethy and Beaudet, 1989), silver grains found over interfaces involving either a perikaryal or a dendritic plasma membrane could be taken to originate from radiation sources associated with the membrane of these perikarya or dendrites. On the basis of these assumptions, $46.4 \%$ of "specific" grains were ascribed to either the cytoplasm or plasma membrane of perikarya and dendrites, $17.8 \%$ to unmyelinated axons and axon terminals, and $7.6 \%$ to myelinated axons.

\section{Plasma membrane-associated NTRH labeling}

Most of the plasma membrane-associated NTRH immunoreactivity was detected on dendrites $(15.6 \%$ of total and $66 \%$ of membrane-associated gold particles) (Figs. 2, 4a). Immunogold 

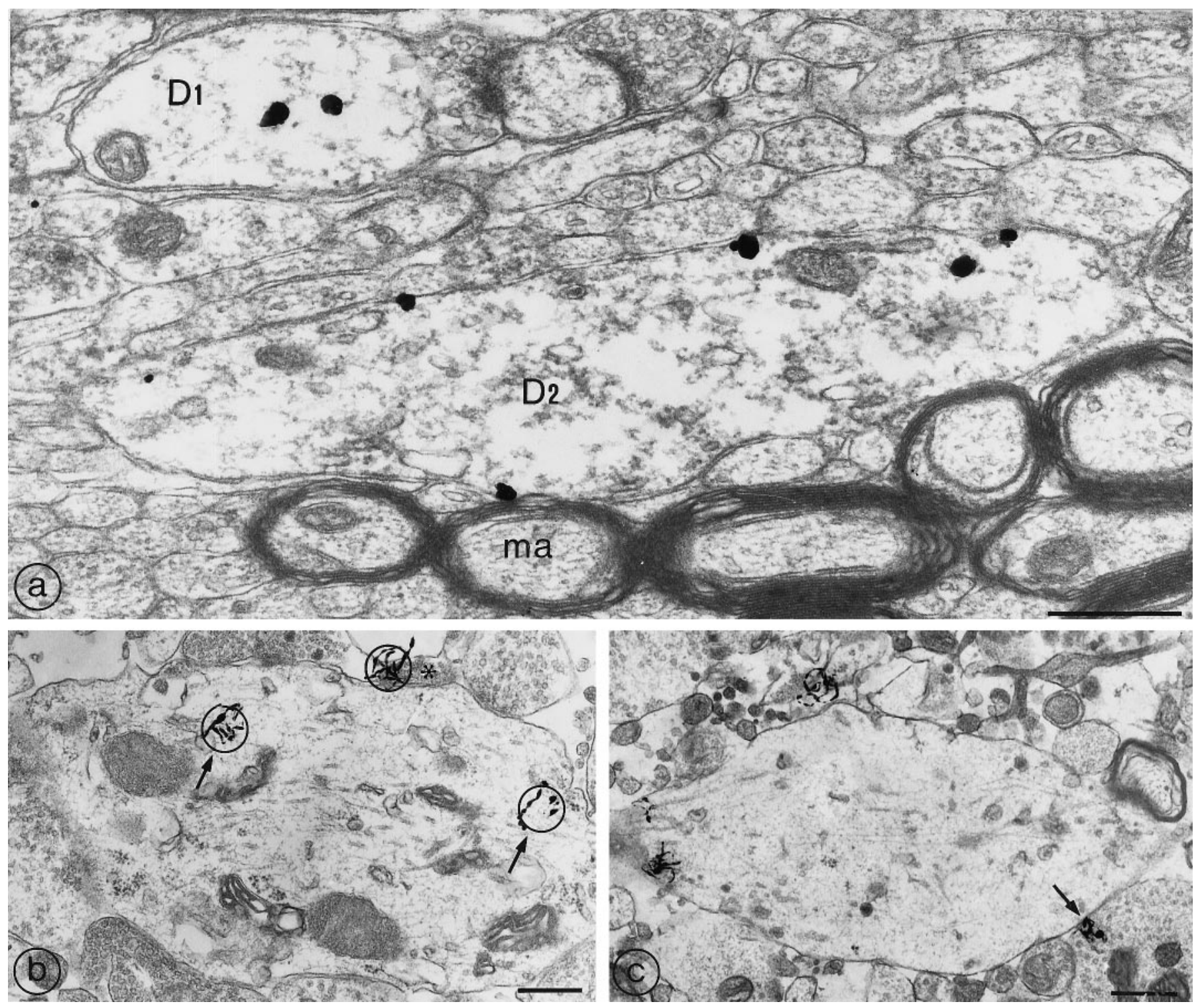

Figure 4. Dendritic shafts immunolabeled for NTRH $(a)$ and radioautographically labeled for ${ }^{125}$ I-NT binding sites $(b, c)$. In $a$, one of the dendrites (D1) shows only intracellular labeling; the other (D2) is labeled predominantly on its plasma membrane. Three gold particles are found opposite unmyelinated and one opposite myelinated axons $(m a)$. In $b$, resolution circles of the size used for statistical distribution analysis help to differentiate exclusive (intracellular; arrows) from shared (membrane-associated) labeled sites. This labeled profile exhibits a single shared grain at the level of an abutting axon terminal $\left(^{*}\right)$. In $c$, all grains decorate the plasma membrane of the labeled dendrite. One of these encroaches on the plasma membrane of an adjacent axon terminal (arrow). Scale bars: $a, 0.6 \mu \mathrm{m} ; b, c, 1 \mu \mathrm{m}$.

particles were usually located on the cytoplasmic side of the plasma membrane, consistent with the intracellular location of the sequence against which the antibodies were generated. Similarly, in electron microscopic radioautograms, shared silver grains arising from specifically bound ${ }^{125} \mathrm{I}-\mathrm{NT}$ molecules were predominantly seen at membrane interfaces involving dendrites $(31.7 \%$ of total and $60 \%$ of shared grains) (Table 1, Fig. $4 b, c$ ).

The distribution of NTRH immunoreactivity along dendritic plasma membranes was remarkably similar to the surface occupancy of the different abutting elements (Figs. 4a, 5, 6). In other words, no particular zone of the plasma membrane showed any specific enrichment in NTRH protein. Similarly, the distribution of ${ }^{125} \mathrm{I}-\mathrm{NT}$ binding sites closely paralleled the occurrence frequency of cellular elements in apposition with dendrites (Figs. $4 b, c, 5,6)$. There was, however, a slightly higher proportion of real grains than hypothetical grains opposite abutting dendrites and a lower one opposite glia (Fig. 6).

The largest contingent of labeled receptors on dendrites was found opposite axon terminals (which also represented the main population of elements facing dendrites) (Figs. 5a,b, 6). These terminals exhibited the same type of morphological features in immunoreacted sections as they did in radiolabeled sections. All were filled with numerous clear synaptic vesicles and only rarely contained large dense-core vesicles (Figs. 4b,c, 5a,b). Four percent of immunoreactive and $7 \%$ of radiolabeled receptors associated with dendritic membranes were detected over a synaptic specialization. Again, this proportion was the same as the occurrence frequency of synapses on labeled dendrites (Fig. 6). Labeled synapses usually exhibited a highly differentiated postsynaptic density typical of asymmetric synapses (Fig. $5 a$ ). 


\begin{tabular}{|c|c|c|c|}
\hline Compartment $^{b}$ & $\begin{array}{l}\text { Real grains: } \\
\text { specific }^{c}\end{array}$ & $\begin{array}{l}\text { Real grains: } \\
\text { nonspecific }\end{array}$ & $\begin{array}{l}\text { Hypothetical } \\
\text { grains }\end{array}$ \\
\hline \multicolumn{4}{|l|}{ Exclusive grains } \\
\hline Soma & $8.0 \pm 1.2$ & $7.9 \pm 1.9$ & $7.7 \pm 1.4$ \\
\hline Dendrites & $11.3 \pm 1.8$ & $8.2 \pm 1.1$ & $8.4 \pm 0.7$ \\
\hline Axon terminals & $9.3 \pm 1.6$ & $7.2 \pm 1.6$ & $11.2 \pm 1.2$ \\
\hline Myelinated axons & $1.7 \pm 0.7$ & $1.6 \pm 0.4$ & $2.2 \pm 0.5$ \\
\hline Glia & $4.0 \pm 0.7$ & $3.8 \pm 0.6$ & $5.7 \pm 0.7$ \\
\hline Blood vessels & $3.2 \pm 1.9$ & $4.2 \pm 1.5$ & $2.3 \pm 1.0$ \\
\hline \multicolumn{4}{|l|}{ Shared grains } \\
\hline Dendrite/terminal & $17.0 \pm 3.0$ & $10.3 \pm 2.6$ & $6.5 \pm 0.9$ \\
\hline Dendrite/dendrite & $1.9 \pm 0.6$ & $0.2 \pm 0.1$ & $0.3 \pm 0.2$ \\
\hline Dendrite/axon & $3.5 \pm 1.2$ & 0 & $2.1 \pm 0.1$ \\
\hline Dendrite/glia & $2.7 \pm 0.6$ & $3.7 \pm 2.1$ & $1.9 \pm 0.3$ \\
\hline Terminal/soma & $2.0 \pm 0.7$ & 0 & $0.3 \pm 0.1$ \\
\hline Terminal/terminal & $3.4 \pm 1.1$ & $8.8 \pm 3.0$ & $5.3 \pm 0.9$ \\
\hline Terminal/axon & $3.5 \pm 1.5$ & $1.4 \pm 1.0$ & $5.7 \pm 1.1$ \\
\hline Terminal/glia & $1.4 \pm 0.6$ & $5.1 \pm 1.9$ & $4.0 \pm 0.5$ \\
\hline Axon/axon & $1.6 \pm 0.7$ & 0 & $1.2 \pm 0.7$ \\
\hline Axon/glia & $3.7 \pm 1.0$ & $0.2 \pm 0.2$ & $1.5 \pm 0.4$ \\
\hline Myelin/myelinated axon & $5.9 \pm 1.1$ & $11.9 \pm 3.7$ & $10.8 \pm 2.2$ \\
\hline Others $^{d}$ & $15.9 \pm 2.2$ & $25.5 \pm 3.0$ & $22.9 \pm 2.3$ \\
\hline
\end{tabular}

$\overline{{ }^{a} \text { Expressed as percentage of total } \pm \text { SEM. Mean of six sections (total binding) and }}$ four sections (nonspecific binding) from four animals.

${ }^{b}$ Compartments containing $>1 \%$ of "specific grains." "Axon" refers to unmyelinated axons.

${ }^{c}$ Difference between total and nonspecific binding as described in Materials and Methods. Significantly different from both nonspecific binding $(p<0.001)$ and hypothetical grain distributions $(p<0.001)$.

${ }^{d}$ Compartments containing $<1 \%$ of specific grains or unidentified profiles.

The second largest contingent of membrane-associated dendritic receptors was found opposite unmyelinated axons and glial cells (Fig. 6). Unmyelinated axons were small $(<0.5 \mu \mathrm{m}$ in diameter) and usually ran in tight bundles, perpendicular or obliquely to the plane of section (Fig. $4 a$ ). Glial elements consisted of thin astroglial leaflets that often enclosed the labeled dendrites over parts of their surface (Figs. $5 c, d$ ). As shown in Figure 6 (compare $a, b)$, both the frequency with which unmyelinated axons and glial profiles were found to abut labeled dendrites and the proportion of receptors present at these appositions were higher in immunoreacted (Fig. 6a) than in radioautographically labeled (Fig. 6b) tissue.

\section{Intracellular NTRH labeling}

In sections of rat SN immunoreacted for the NTRH, $73 \%$ of the total number of gold particles were intracellular. A smaller proportion of specific ${ }^{125} \mathrm{I}-\mathrm{NT}$ binding sites detected in the same region were ascribed to intracellular radioactive sources [40\% of identifiable specific grains (Table 1)].

The percentage of intracellular immunogold particles was approximately the same in dendrites, terminals, and glial cells [between 70 and $80 \%$ (Fig. 2)] but was higher in nerve cell bodies and myelinated axons, where it reached 93 and 100\% of total, respectively (Fig. 2). Nonmyelinated axons exhibited equivalent amounts of intracellular and membrane-associated gold particles. Surface measurements showed no correlation between the size of immunoreactive dendrites and the number of intracellular gold particles.

Intracellular ${ }^{125} \mathrm{I}-\mathrm{NT}$ binding sites were proportionally as nu- merous as immunogold particles inside nerve cell bodies, myelinated axons, and glia (Fig. 7). However, they were considerably less concentrated than immunogold particles inside dendrites. A much lower density of silver grains than immunogold particles was also detected over unmyelinated axons, but this most likely reflects mainly the fact that most of these unmyelinated axons had a diameter smaller than that of the radioautographic resolution circle.

In neuronal perikarya, some of the immunogold particles and radioautographic silver grains directly overlaid the endoplasmic reticulum, Golgi apparatus, and mitochondria (Fig. 3a,b). Except for the endoplasmic reticulum, in which the proportion of intrasomatic immunogold particles was slightly higher than that of silver grains, the proportions of the two labels observed over these different structures were remarkably similar (Fig. 8). In addition, $\sim 7 \%$ of gold particles were associated with vesicular elements of various sizes and shapes. Because of the small size of these intracellular vesicles relative to the resolution of the radioautographic technique, no attempt was made at ascribing silver grains to them. The remaining immunogold particles and autoradiographic grains were located within the cytoplasm, with no apparent association with specific organelles.

In neuronal cell bodies exhibiting NTRH immunolabeling, up to $25 \%$ of total perikaryal grains were observed over the nucleus (Fig. 8). Similarly, $\sim 20 \%$ of intraperikaryal radioautographic silver gold particles were visible over the nucleus and the nuclear membrane (Fig. 8).

Within dendrites, the most frequently labeled organelles were mitochondria for both markers ( $15 \%$ of intradendritic labeling). Approximately $7 \%$ of intradendritic immunogold particles were associated with vesicular elements, many of which were morphologically identifiable as endosomes. These were occasionally seen close to the plasma membrane, in either cell bodies or dendrites (Fig. 9). Again, in view of the small diameter of these vesicles relative to the resolution of the radioautographic technique, no attempt was made at linking intracellular silver grains to these organelles. The remaining immunogold and radioautographic labeling was located within the cytoplasm, with no obvious association with specific organelles.

\section{DISCUSSION}

The present study provides the first direct ultrastructural evidence that immunocytochemical labeling of NTRH identifies functional binding sites along plasma membranes of dendrites in the SN. Comparison of the subcellular distribution of receptor proteins and receptor binding sites also provides new insight into the functionality, regulation, and targeting of this receptor subtype in midbrain, presumptive DA neurons.

\section{Methodological considerations}

NTRH immunocytochemical staining relied on the use of a recently developed, affinity-purified NTRH polyclonal antiserum, the specificity of which has been extensively characterized (Boudin et al., 1995, 1996). Further support for specificity was provided here by the absence of immunoreactivity in sections incubated with the antiserum preabsorbed with the immunogenic peptide.

Radioautographic labeling of ${ }^{125} \mathrm{I}-\mathrm{NT}$ binding sites relied on a technique previously shown to provide selective and sensitive ultrastructural detection of high-affinity (i.e., levocabastine insensitive) NT binding sites in rat ventral tegmental area (Dana et al., 1989) and basal forebrain (Szigethy et al., 1990). Specific ${ }^{125} \mathrm{I}-\mathrm{NT}$ 

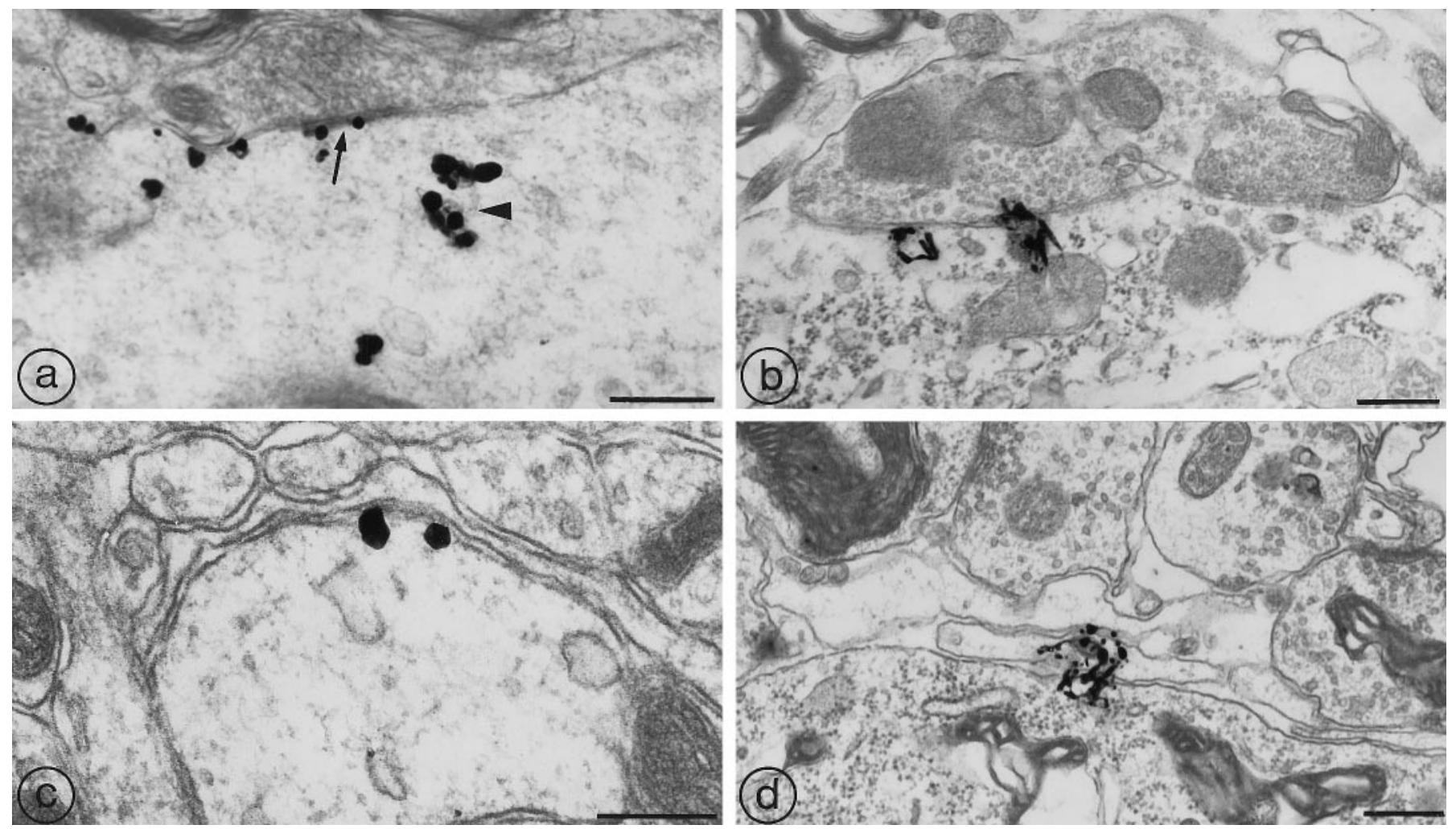

Figure 5. NTRH proteins $(a, c)$ and ${ }^{125}$ I-NT binding sites $(b, d)$ associated with dendritic plasma membranes in rat substantia nigra. In the top panels, gold particles $(a)$ as well as radioautographic grains $(b)$ are detected over axodendritic contacts. In $a$, an asymmetric synaptic specialization is clearly visible at the site of contact (arrow). In $b$, there is no obvious synaptic specialization in the plane of section. Both abutting terminals contain densely packed clear synaptic vesicles. In $a$, note the high density of gold particles associated with intradendritic vesicles (arrowhead). In the bottom panels, gold particles $(c)$ and radioautographic grains $(d)$ associated with dendritic plasma membranes are detected opposite thin astroglial sheaths. Scale bars, $0.5 \mu \mathrm{m}$.

binding on average accounted for $66 \%$ of total binding remaining in sections after fixation and dehydration. The regional distribution of this specific labeling was similar before and after crosslinking of bound radioligand molecules to tissue proteins with glutaraldehyde, indicating that fixation/dehydration steps had not artifactually translocated specifically bound molecules from their receptors.

Additional support for the specificity of immunolabeling and radiolabeling patterns stemmed from the similarity between the light microscopic distributions of NTRH immunoreactivity and specific ${ }^{125}$ I-NT binding in the rat SN and from the fact that by electron microscopy both markers were mainly found in association with neuronal perikarya and dendrites. Furthermore, comparable proportions of silver grains and immunogold particles were detected over myelinated and unmyelinated axons, axon terminals, and glial leaflets.

\section{Immunogold identifies plasmalemmal NTRH binding sites}

Significant fractions of both immunoreactive NTRH and radiolabeled ${ }^{125} \mathrm{I}-\mathrm{NT}$ binding sites were associated with neuronal plasma membranes. In addition, the relative distributions of NTRH receptor proteins and of ${ }^{125}$ I-NT binding sites along neuronal plasma membranes were remarkably similar, indicating that (1) the distribution of membrane-associated NTRH reflects that of functional receptors, i.e., of receptors that have the potential to bind the ligand, and (2) any spare receptor present at the surface of neurons would have an ultrastructural distribution similar to that of functional ones.
The frequency with which labeled receptors were detected opposite the various elements abutting dendrites was almost identical to that with which these elements contacted labeled dendrites, indicating that both immunoreactive and radiolabeled NTRH are homogeneously distributed along dendritic membranes. In particular, there was no enrichment of labeled receptors at the level of incoming axon terminals, whether or not these exhibited a synaptic specialization. It may be argued that the incidence and/or enrichment of synaptic labeling might have been higher if we had used post-embedding as opposed to preembedding immunolabeling, because the former has been claimed to be less susceptible than the latter to poor penetration of immunoreagents in the synaptic cleft (Nusser et al., 1996; Bernard et al., 1997). However, it is unlikely that the lack of synaptic enrichment observed in the present study was caused by technical factors, because the incidence of synaptic labeling was identical in immunohistochemical and autoradiographic material. Furthermore, immunocytochemical studies on other G-proteincoupled receptors have revealed comparable distributions of immunoreactive receptors in pre-embedded and post-embedded material (Baude et al., 1993; Luján et al., 1997) and excellent penetration of immunoreagents in the synapse using preembedding approaches (Shigemoto et al., 1996). The present data therefore suggest that, as shown previously in the ventral tegmental area (Dana et al., 1989) and the basal forebrain (Szigethy et al., 1990), NT acts mainly extrasynaptically in the SN. Whether synaptic receptors play a specific and/or a preferential role with regard to the transduction of NT's effects on nigral cells remains 


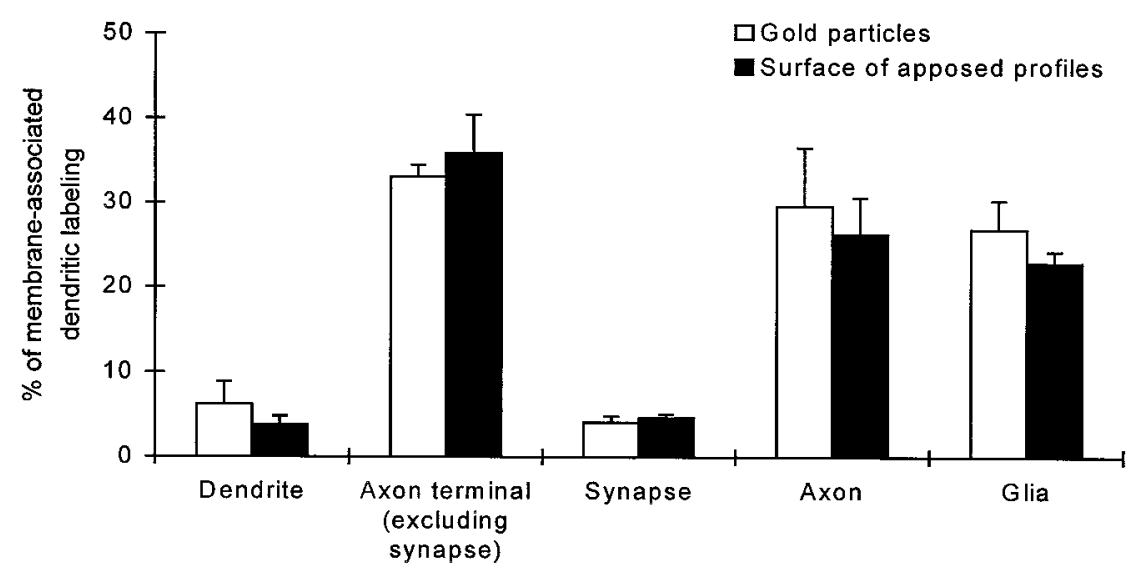

Figure 6. Distribution of NTR immunoreactivity $(a)$ and of specific ${ }^{125}$ I-NT binding $(b)$ sites along dendritic plasma membranes. $a$, The proportion of dendritic membrane-associated gold particles facing each type of abutting element is expressed as a percentage of the total number of gold particles associated with dendritic membranes. The proportion of membrane length occupied by these different elements is expressed as a percentage of total dendritic perimeter. Values are the mean \pm SEM from three animals. $b$, The distribution of specific ${ }^{125} \mathrm{I}-\mathrm{NT}$ binding sites along dendritic plasma membrane is derived from the labeling frequency of membrane interfaces involving dendrites and expressed as a percentage of shared grains associated with dendrites. The frequency with which dendritic membranes were contacted by its different abutting elements is similarly derived from the occurrence frequency of hypothetical shared grains overlying membrane interfaces involving dendrites. Values are the mean \pm SEM of six sections from four animals.
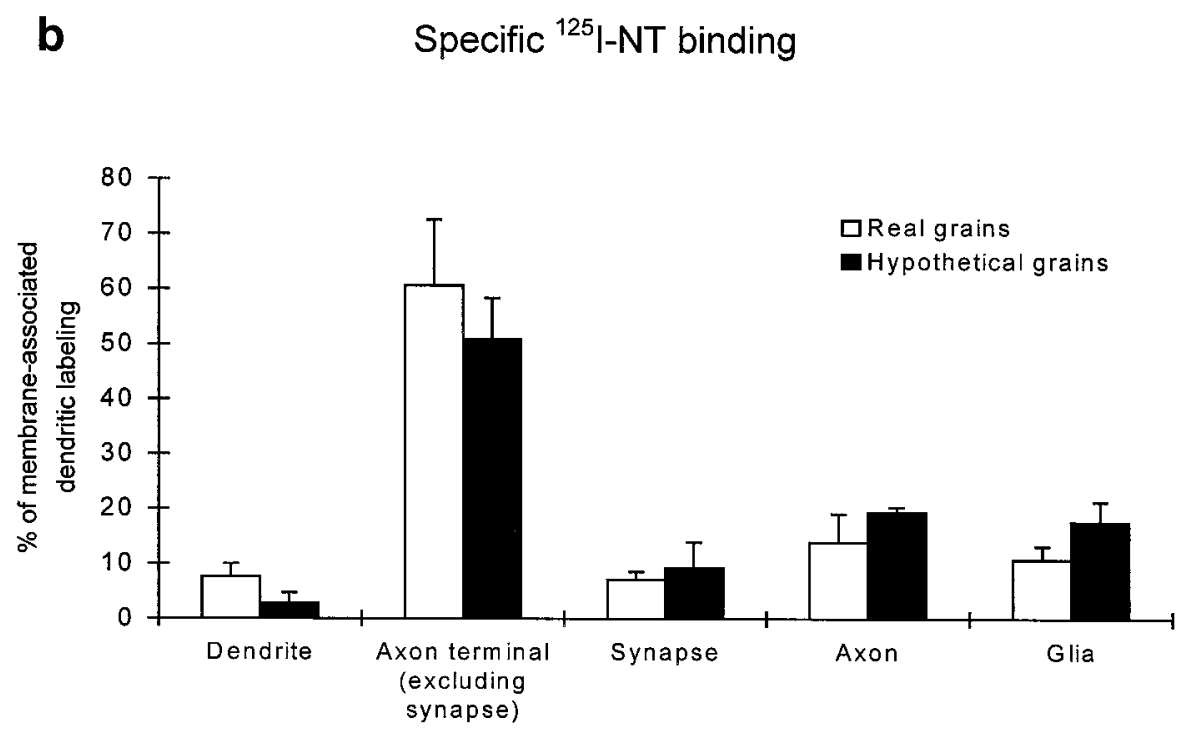

to be determined. In any event, labeled synapses are unlikely to be established by afferent NT axons, given the rare occurrence of NT-immunoreactive axon terminals found previously in apposition with DA cells in the SN (Woulfe and Beaudet, 1992) and the fact that only few terminals presynaptic to labeled dendrites contained the large dense-core vesicles typical of neuropeptide axons.

\section{Immunogold and radioautographic labeling of NTRH are mainly intracellular}

Using either immunogold or radioautographic techniques, we determined that a large proportion of labeled NTRH receptors were intracellular. Similarly, other immunolabeled or radiolabeled neuropeptide receptors, including somatostatin and $\mu$ - and $\delta$-opioid receptors (Pasquini et al., 1992; Cheng et al., 1995; Moyse et al., 1997; Dournaud et al., 1998), were previously reported to be largely intracellular. The intracellular binding of ${ }^{125} \mathrm{I}-\mathrm{NT}$ visualized in the present study is also consistent with the previous demonstration of specific ${ }^{125} \mathrm{I}-\mathrm{NT}$ binding in rat brain slices (Dana et al., 1989; Szigethy et al., 1990) as well as in vesicular fractions obtained from cellular fractionation of rat brain homogenates (Schotte et al., 1988) and neurons in primary culture (Chabry et al., 1993).

A significant fraction of immunolabeled intracellular proteins are likely to correspond to receptors targeted to the plasma membrane. Indeed, a sizeable proportion of immunolabeled receptors detected within nerve cell bodies was associated with the endoplasmic reticulum. A comparable proportion of radioautographically labeled NT binding sites was detected over this structure, implying that newly synthesized receptor proteins detected with the antiserum already possess the molecular and conformational properties required for effective ligand binding. The Golgi apparatus also exhibited a significant amount of both immunoautographic and radioautographic NTR labeling. Localization within the Golgi is congruent with the characterization of NTRH as an $N$-glycosyl-protein (Boudin et al., 1995). The fact that comparable proportions of immunoreactive and labeled receptors were detected within this structure suggests that glycosylations 


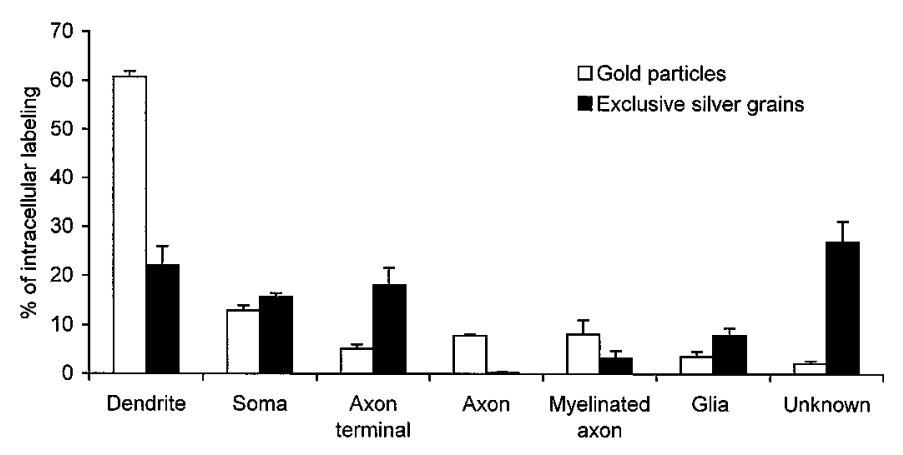

Figure 7. Intracellular distribution of NTRH proteins (gold particles) and ${ }^{125}$ I-NT binding sites (exclusive silver grains) in rat substantia nigra. Data are expressed as percentage of the total number of intracellular gold particles for NTRH and of the total number of exclusive grains for ${ }^{125} \mathrm{I}-\mathrm{NT}$ binding sites. Values are the mean \pm SEM from three (immunocytochemistry; total particles counted: 1950) and four (radioautography; total grains counted: 1632) animals.

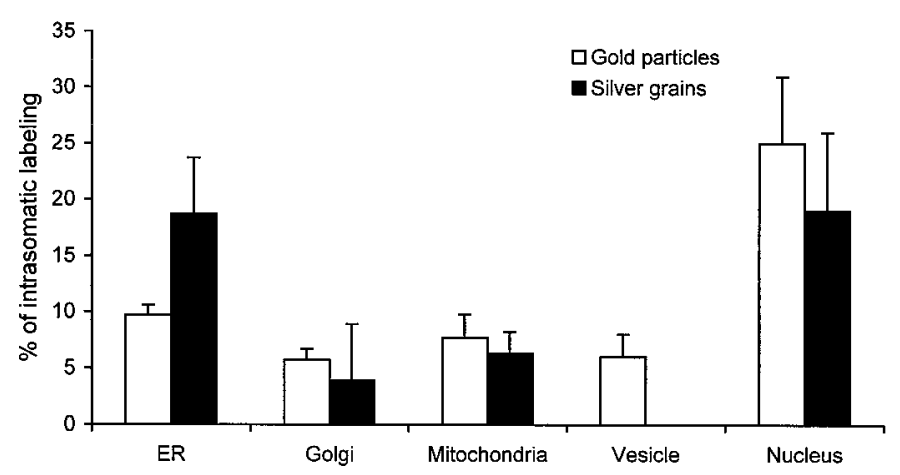

Figure 8. Intrasomatic distribution of NTRH receptor proteins (gold particles) and ${ }^{125} \mathrm{I}-\mathrm{NT}$ binding sites (silver grains) in rat substantia nigra. The number of gold particles and of silver grains associated with endoplasmic reticulum $(E R)$, Golgi apparatus (Golgi), mitochondria, vesicles, and nucleus was recorded and expressed as a percentage of total intracellular somatic labeling. Values are the mean \pm SEM from three (immunocytochemistry) and four (radioautography) animals.

are not necessary for efficient NT binding. This observation is consistent with the high level of ${ }^{125}$ I-NT binding to NTRH expressed in Escherichia coli bacteria, a cellular system that produces only nonglycosylated proteins (Grisshammer et al., 1993; Tucker and Grisshammer, 1996).

Using either marker, we detected a substantial fraction of perikaryal labeling over the nucleus. This labeling appeared specific, because no nuclear labeling was detected in otherwise NTRH-immunonegative cells. This nuclear immunoreactivity may correspond to neosynthesized receptors, because the nuclear envelope has long been recognized as a major site of protein synthesis (Puddington et al., 1985). Alternatively, nuclear immunoreactivity may reflect nuclear translocation of internalized NTRH or of a fragment thereof (Laduron, 1992). Such a translocation might regulate genomic expression in target cells and could thereby account for the upregulation of tyrosine hydroxylase mRNA observed after ${ }^{125} \mathrm{I}-\mathrm{NT}$ internalization in vivo within midbrain DA cells (Burgevin et al., 1992).

\section{Immunogold labeling reveals dendritic cytoplasmic NTRHs that are not recognized by ${ }^{125} \mathrm{I}-\mathrm{NT}$}

In contrast to neuronal perikarya, which contained approximately equal proportions of immunolabeled and radiolabeled NTRHs, dendrites exhibited a threefold higher concentration of immunolabeled than radiolabeled cytoplasmic receptors. It is unlikely that all of these receptors belong to the neosynthesized pool of receptors originating from nerve cell bodies because, as discussed above, our own observations suggest that NTRH proteins possess an appropriate conformation for ligand binding immediately on synthesis. A more likely interpretation is that the immunoreactive but nonradiolabeled receptors detected inside dendrites correspond to receptors in the course of internalization, endosomal migration, and degradation. The association of immunogold particles with endosome-like vesicles observed within certain dendrites supports this interpretation. It is also consistent with the recent demonstration of receptor-mediated somatodendritic internalization of fluorescent NT in the rat SN (Faure et al., 1995) as well as in DA neurons in culture (Nouel et al., 1997). Such an interpretation would imply that internalized receptors either do not have the proper conformation and/or coupling state to recognize the exogenous ligand or their sequestration in endosomes may render them physically unaccessible to our radioactive probe. Further experiments will be needed to explore these different possibilities.

\section{Comparable proportions of axonal and glial labeling are identified by immunogold labeling and radioautography}

The immunogold particles and radioautographic grains observed inside myelinated and unmyelinated axons likely represent NTRH in transit between SN DA nerve cell bodies and their terminal fields in the neostriatum. Anterograde migration of receptors toward the neostriatum is congruent with the previous demonstration of axonal transport of NT receptors (Kessler and Beaudet, 1989) and of their association with DA axon terminals in this structure (Palacios and Kuhar, 1981; Quirion et al., 1985; Hervé et al., 1986; Masuo et al., 1990).

The presence of NTRH immunoreactivity and radioautographic labeling within axon terminals in the SN suggests that NT may presynaptically regulate the release of neurotransmitters in this structure. These NTRH-containing terminals could belong to a striatonigral pathway involving GABA or enkephalin (Gerfen et al., 1982; Berendse et al., 1992), given the presence of NTRHimmunopositive perikarya documented in the ventral striatum (Boudin et al., 1996).

Finally, a small but significant proportion of NTRH immunoreactivity as well as of ${ }^{125} \mathrm{I}-\mathrm{NT}$ binding sites were found in association with astroglial cells. Earlier studies on astrocytes grown in culture from rat cerebral cortex had led us to believe that only the low-affinity NT binding site, sensitive to levocabastine, was expressed by glial cells (Nouel et al., 1997). The present results suggest that there is either a regional difference in the glial expression of the NTRH or that this expression is dependent on factors present in the adult rat brain but absent in cultures from neonatal rats. The association of the NTRH with astroglial cells (as well as with non-DA axon terminals) in the SN could account for the residual ${ }^{125}$ I-NT binding observed after selective destruction of SN DA neurons by 6-hydroxydopamine (Palacios and Kuhar, 1981; Quirion et al., 1985; Hervé et al., 1986; Masuo et al., 1990).

In conclusion, the present study provides the first electron microscopic evidence that the distribution of NTRH receptor proteins labeled by the NTR antiserum reflects that of NT binding sites on the plasma membrane of presumptive DA cells in the SN. This result implies that wherever the portion of the 

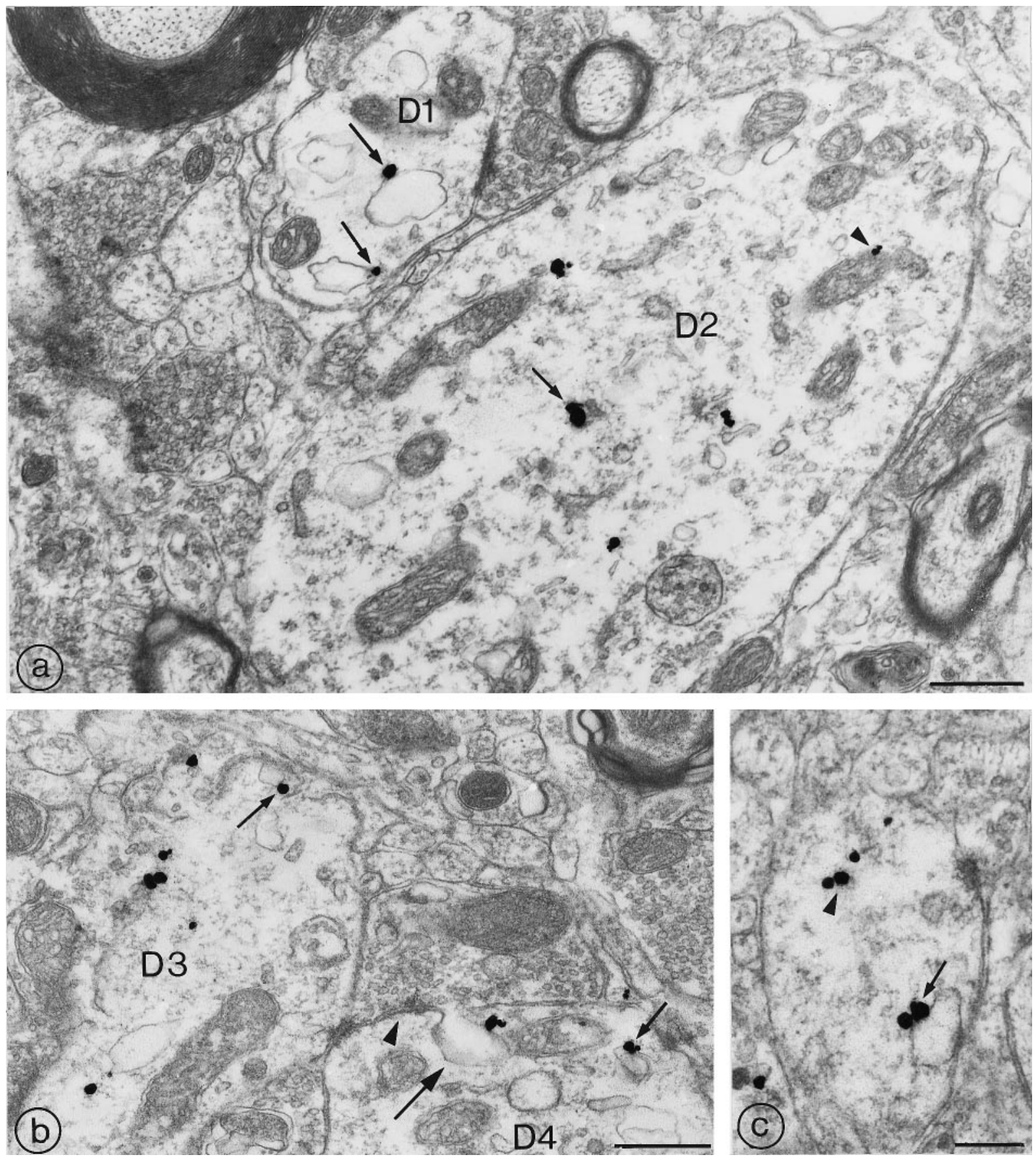

Figure 9. NTRH-immunoreactive dendrites in rat substantia nigra. Intracellular receptors. $a$, Two NTRH-immunoreactive dendritic shafts (D1, D2) in which immunolabeled receptors are exclusively intracellular. In D1, gold particles are associated with the outer limiting membrane of large endocytic vesicles (arrows). In D2, immunogold particles are associated with a mitochondrion (arrowhead) or with small, secretory-type vesicles (arrows). $b$, Two NTRH-immunoreactive shafts $(D 3, D 4)$, one of which $(D 4)$ receives a symmetrical synaptic contact from an unlabeled terminal (arrowhead). In both dendrites, immunogold particles are seen in association with the outer membrane of endosomal vesicles (arrows). Note that the vesicle facing the axon terminal is in the process of endocytosis (large arrow). $c$, A single NTRH-labeled dendrite showing intracellular receptors associated either with a large, endocytotic-type vesicle (arrow) or with a small, secretory-type vesicle (arrowhead). Scale bars: $a, b, 0.5 \mu \mathrm{m} ; c, 0.2 \mu \mathrm{m}$.

neuronal plasma membrane to which a receptor protein has been targeted, it possesses the ability to bind NT. In addition, we have shown that the receptor is distributed in a homogeneous manner along extrasynaptic plasma membranes and is also present within certain axodendritic synaptic junctions. Finally, our results demonstrate the potential importance of immunocytochemical neu- ropeptide receptor labeling for identification of internalized receptors that have reduced ability to bind their ligand.

\section{REFERENCES}

Baude A, Nusser Z, Roberts JDB, Mulvihill E, McIlhinney RAJ, Somogyi P (1993) The metabotropic glutamate receptor (mGluR1 $\alpha$ ) is con- 
centrated at perisynaptic membrane of neuronal subpopulations as detected by immunogold reaction. Neuron 11:771-787.

Bayer VE, Towle AC, Pickel VM (1991) Ultrastructural localization of neurotensin-like immunoreactivity within dense core vesicles in perikarya, but not terminals, colocalizing tyrosine hydroxylase in the rat ventral tegmental area. J Comp Neurol 311:179-196.

Beaudet A (1993) Autoradiographic localization of receptors at the electron microscopic level. In: Receptor autoradiography. Principles and practices (Wharton J, Polak JM, eds), pp 135-158. Oxford: Oxford UP.

Berendse HW, Groenewegen HJ, Lohman AH (1992) Compartmental distribution of ventral striatal neurons projecting to the mesencephalon in the rat. J Neurosci 12:2079-2103.

Bernard V, Somogyi P, Bolam JP (1997) Cellular, subcellular, and subsynaptic distribution of AMPA-type glutamate receptor subunits in the neostriatum of the rat. J Neurosci 17:819-833.

Boudin H, Gruaz-Guyon A, Faure MP, Forgez P, Lhiaubet AM, Dennis M, Beaudet A, Rostène W, Pélaprat D (1995) Immunological recognition of different forms of the neurotensin receptor in transfected cells and rat brain. Biochem J 305:277-283.

Boudin H, Pélaprat D, Rostène W, Beaudet A (1996) Cellular distribution of neurotensin receptors in rat brain: immunohistochemical study using an antipeptide antiserum against the cloned high affinity receptor. J Comp Neurol 373:76-89.

Burgevin MC, Castel MN, Quarteronet D, Chevet T, Laduron PM (1992) Neurotensin increases tyrosine hydroxylase messenger RNApositive neurons in substantia nigra after retrograde axonal transport. Neuroscience 49:627-633.

Cador MA, Kelly AE, LeMoal M, Stinus L (1985) Behavioural analysis of the effect of neurotensin injection into the ventral mesencephalon on investigatory and spontaneous motor behaviour in the rat. Psychopharmacology 85:187-196.

Chabry J, Gaudriault G, Vincent JP, Mazella J (1993) Implication of various forms of neurotensin receptors in the mechanism of internalization of neurotensin in cerebral neurons. $J$ Biol Chem 268:17138-17144.

Chalon P, Vita N, Kaghad M, Guillemot M, Bonnin J, Delpech B, LeFur G, Ferrera P, Caput D (1996) Molecular cloning of a levocabastinesensitive neurotensin binding site. FEBS Lett 386:91-94.

Chan J, Aoki C, Pickel VM (1990) Optimization of differential immunogold-silver and peroxidase labeling with maintenance of ultrastructure in brain sections before plastic embedding. J Neurosci Methods 33:113-127.

Cheng PY, Svingos AL, Wang H, Clarke CL, Jenab S, Beczkowska IW, Inturrisi CE, Pickel VM (1995) Ultrastructural Immunolabeling shows prominent presynaptic vesicular localization of $\delta$-opioid receptor within both enkephalin- and nonenkephalin-containing axon terminals in the superficial layers of the rat cervical spinal cord. J Neurosci 15:5976-5988.

Chien PY, Farkas RH, Nakajima S, Nakajima Y (1996) Single-channel properties of the nonselective cation conductance induced by neurotensin in dopaminergic neurons. Proc Natl Acad Sci USA 93:14917-14921.

Dana C, Vial M, Leonard K, Beauregard A, Kitabgi P, Vincent JP, Rostène W, Beaudet A (1989) Electron microscopic localization of neurotensin binding sites in the midbrain tegmentum of the rat. I. Ventral tegmental area and interfascicular nucleus. J Neurosci 9:2247-2257.

Dournaud P, Boudin H, Shonbrunn A, Tannenbaum G, Beaudet A (1998) Interrelationships between somatostatin sst2A receptors and somatostatin-containing axons in rat brain: evidence for regulation of cell surface receptors by endogenous somatostatin. J Neurosci 18:1056-1071.

Faure MP, Nouel D, Beaudet A (1995) Axonal and dendritic transport of internalized neurotensin in rat mesostriatal dopaminergic neurons. Neuroscience 68:519-529.

Ford AP, Mardsen CA (1990) In vivo neurochemical and behavioural effects of intracerebrally administered neurotensin and D-Trp11neurotensin on mesolimbic and nigrostriatal dopaminergic function in the rat. Brain Res 534:243-250.

Gerfen CR, Staines WA, Arbuthnot GW, Fibiger HC (1982) Crossed connections of the substantia nigra in the rat. J Comp Neurol 207:283-303

Grisshammer R, Duckworth R, Henderson R (1993) Expression of a rat neurotensin receptor in Escherichia coli. Biochem J 295:571-576.

Hamel E, Beaudet A (1987) Opioid receptors in rat neostriatum: radio- autographic distribution at the electron microscopic level. Brain Res 401:239-257.

Hervé D, Tassin JP, Studler JM, Dana C, Kitabgi P, Vincent JP, Glowinski J, Rostène W (1986) Dopaminergic control of ${ }^{125}$ I-labeled neurotensin binding site density in corticolimbic structures of the rat brain. Proc Natl Acad Sci USA 83:6203-6207.

Hökfelt T, Everitt E, Theodorson-Noerheim E, Goldstein M (1984) Occurrence of neurotensin-like immunoreactivity in subpopulations of hypothalamus, mesencephalic and medullary catecholamine neurons. J Comp Neurol 222:543-559.

Jennes L, Stumpf WE, Kalivas PW (1982) Neurotensin: topographical distribution in rat brain by immunohistochemistry. J Comp Neurol 210:211-224.

Jiang ZG, Pessia M, North RA (1994) Neurotensin excitation of rat ventral tegmental neurons. J Physiol (Lond) 474:119-129.

Kalivas PW, Burgess SK, Nemeroff CB, Prange AJ (1983) Behavioral and neurochemical effects of neurotensin microinjection into the ventral tegmental area of the rat. Neuroscience 8:495-505.

Kalivas PW, Nemeroff CB, Miller JS, Prange AJ (1985) Microinjection of neurotensin into the ventral tegmental area produces hypothermia: evaluation of dopamine mediation. Brain Res 326:219-227.

Kasckow J, Nemeroff CB (1991) The neurobiology of neurotensin: focus on NT-DA interactions. Regul Pept 36:153-164.

Kessler JP, Beaudet A (1989) Association of neurotensin binding sites with sensory and visceromotor components of the vagus nerve. J Neurosci 9:466-472.

Laduron PM (1992) Genomic pharmacology: more intracellular sites for drug action. Biochem Pharmacol 47:3-13.

Luján R, Roberts JDB, Shigemoto R, Ohishi H, Somogyi P (1997) Differential plasma membrane distribution of metabotropic glutamate receptors $\mathrm{mGluR} 1 \alpha$, mGluR2 and $\mathrm{mGluR} 5$, relative to neurotransmitter release sites. J Chem Neuroanat 13:219-241.

Marcel D, Pollard H, Verroust P, Schwartz JC, Beaudet A (1990) Electron microscopic localization of immunoreactive enkephalinase (EC 3.4.24.11) in the neostriatum of the rat. J Neurosci 10:2804-2817.

Masuo Y, Pélaprat D, Montagne MN, Scherman D, Rostène W (1990) Regulation of neurotensin-containing neurons in the rat striatum and substantia nigra. Effects of unilateral nigral lesions with 6hydroxydopamine on neurotensin content and its binding density. Brain Res 510:203-210.

Mazella J, Botto JM, Guillemare E, Coppola T, Sarret P, Vincent JP (1996) Structure, functional expression, and cerebral localization of the levocabastine-sensitive neurotensin/neuromedin $\mathrm{N}$ receptor from mouse brain. J Neurosci 16:5613-5620.

Moyse E, Marcel D, Leonard K, Beaudet A (1997) Electron microscopic distribution of mu opioid receptors on noradrenergic neurons of the locus coeruleus. Eur J Neurosci 9:128-139.

Myers RD, Lee TF (1983) In vivo release of dopamine during perfusion of neurotensin in the substantia nigra of the unrestrained rat. Peptides 4:955-961.

Napier TC, Gay DA, Hulebak KL, Breese GR (1985) Behavioral and biochemical assessment of time-related changes in globus pallidus and striatal dopamine induced by intranigrally administered neurotensin. Peptides 6:1057-1068.

Nicot A, Bérod A, Rostène W (1995) Differential expression of neurotensin receptor mRNA in the dopaminergic cell groups of the rat diencephalon and mesencephalon. J Neurosci Res 40:667-674.

Nouel D, Faure MP, St Pierre JA, Alonso R, Quirion R, Beaudet A (1997) Differential binding profile and internalization process of neurotensin via neuronal and glial receptors. J Neurosci 17:1795-1803.

Nusser Z, Sieghart W, Stephenson FA, Somogyi P (1996) The $\alpha 6$ subunit of the $\mathrm{GABA}_{\mathrm{A}}$ receptor is concentrated in both inhibitory and excitatory synapses on cerebellar granule cells. J Neurosci 16:103-114.

Palacios JM, Kuhar MJ (1981) Neurotensin receptors are located on dopaminergic-containing neurons in rat midbrain. Nature 294:587-589.

Pasquini F, Bochet P, Garbay-Jaureguiberry C, Roques BP, Rossier J, Beaudet A (1992) Electron microscopic localization of photoaffinitylabelled delta opioid receptors in the neostriatum of the rat. J Comp Neurol 326:229-244.

Peters A, Palay SL, Webster H deF (1991) The fine structure of the central nervous system. Neurons and their supporting cells. New York: Oxford UP.

Pinnock RD (1985) Neurotensin depolarizes substantia nigra dopamine neurones. Brain Res 338:151-154.

Puddington L, Lively MO, Lyles DS (1985) Role of the nuclear envelope 
in synthesis, processing and transport of membrane glycoproteins. J Biol Chem 260:5641-5647.

Quirion R, Chiueh CC, Everist HD, Pert A (1985) Comparative localization of neurotensin receptors on nigrostriatal and mesolimbic dopaminergic terminals. Brain Res 327:385-389.

Rivest R, Jolicoeur FB, Marsden CA (1991) Neurotensin causes a greater increase in the metabolism of dopamine in the accumbens than in the striatum in vivo. Neuropharmacology 30:25-33.

Sadoul JL, Mazella J, Amar S, Kitabgi P, Vincent JP (1984) Preparation of neurotensin selectively iodinated on the tyrosine 3 residue. Biological activity and binding properties on mammalian neurotensin receptors. Biochem Biophys Res Commun 120:812-819.

Santucci V, Gueudet C, Steinberg R, LeFur G, Soubrié P (1997) Involvement of cortical neurotensin in the regulation of rat meso-cortico-limbic dopamine neurons: evidence from changes in the number of spontaneously active A10 cells after neurotensin receptor blockade. Synapse 26:370-380.

Sarret P, Beaudet A, Vincent JP, Mazella J (1998) Regional and cellular distribution of low affinity neurotensin receptor mRNA in adult and developing mouse brain. J Comp Neurol 394:344-356.

Schotte A, Rostène W, Laduron PM (1988) Different subcellular localization of neurotensin receptor and neurotensin acceptor sites in the rat brain dopaminergic system. J Neurochem 50:1026-1033.

Shi WX, Bunney BS (1992) Actions of neurotensin: a review of the electrophysiological studies. Ann NY Acad Sci 668:129-145.
Shigemoto R, Kulik A, Roberts JDB, Ohishi H, Nusser Z, Kaneko T, Somogyi P (1996) Target-cell-specific concentration of a metabotropic glutamate receptor in the presynaptic active zone. Nature 381:523-525.

Szigethy E, Beaudet A (1989) Correspondence between high affinity ${ }^{125}$ I-neurotensin binding sites and dopaminergic neurons in the rat substantia nigra and ventral tegmental area: a combined radioautographic and immunohistochemical light microscopic study. J Comp Neurol 279:128-137.

Szigethy E, Leonard K, Beaudet A (1990) Ultrastructural localization of $\left[{ }^{125} \mathrm{I}\right]$ neurotensin binding sites to cholinergic neurons of the rat nucleus basalis magnocellularis. Neuroscience 36:377-391.

Tucker J, Grisshammer R (1996) Purification of a rat neurotensin receptor expressed in Escherichia coli. Biochem J 317:891-899.

Wang HL, Wu T (1996) G alpha q/11 mediates neurotensin excitation of substantia nigra dopaminergic neurons. Mol Brain Res 36:29-36.

Woulfe J, Beaudet A (1992) Neurotensin terminals form synapses primarily with neurons lacking detectable tyrosine hydroxylase immunoreactivity in the rat substantia nigra and ventral tegmental area. J Comp Neurol 321:163-176.

Wu T, Li A, Wang HL (1995) Neurotensin increases the cationic conductance of rat substantia nigra dopaminergic neurons through the inositol 1,4,5-triphosphate-calcium pathway. Brain Res 683: 242-250. 